\title{
Across the chessboard of life
}

David L. Hull

The Secular Ark: Studies in the History of Biogeography.

By Janet Browne.

Yale University Press: 1983. Pp.265. \$27.50, f21.

IN The Secular Ark, Janet Browne compares the surface of the Earth to an immense chessboard on which species are distributed. From the beginning the task of the biogeographer was to discern this pattern and to postulate processes that might have produced it.

The Bible provided the $\mathrm{K}-\mathrm{P} 4$ in this game. According to biblical literalists, God created all living creatures in the Garden of Eden. From there they spread across the face of the land only to be annihilated by the Great Flood. After Noah's Ark settled on Mount Ararat, the process was repeated. Although no traces remained of the first great dispersal, early biogeographers were presented with the problem of how giraffes got from Ararat to Africa, armadillos to South America and the partridge to Scotland. As numerous voyages of discovery increased the number of known species, however, the Ark began to strain at its seams. Just as Newtonian physicists relegated problems surrounding action-at-a-distance to the closet, biogeographers simply ignored this problem once it became too intractable and concentrated on the flood itself. For example, Linnaeus never mentions the Ark in his description of the origin of species on a mountainous equatorial island that somehow incorporated all possible habitats. As the ocean surrounding this island receded, organisms spread out from Eden. (Browne relegates Linnaeus's later, more sophisticated views to a single parenthetical aside.)

Browne proceeds rapidly from such early, primitive theories to the more secular views of Alexander von Humboldt (17691859), Augustin de Candolle (1778-1841) and Robert Brown (1773-1858), giving particular attention to de Candolle's "botanical provinces" and Humboldt's "botanical arithmetic". The prevailing view of the time was that species existed in reasonably discrete, integrated natural assemblages or biotas. To aid in their discovery, Humboldt devised an elementary mathematical technique for determining proportions of various sorts of species; just as physicists constructed the periodic table by means of numerical ratios exhibited by the physical elements, Humboldt proposed to analyse the living world. Browne's failure to discuss Linnaeus's later views is especially unfortunate here, because he had already developed a system in which crosses between a few elemental species could generate all derivative species, much in the same way that compounds can be generated by various com- binations of the elements.

Although the enthusiasm for Humboldt's botanical arithmetic was shortlived, it did fire the imagination of one budding geologist-naturalist - Charles Darwin (1809-1882). The theories of such geologists as Charles Lyell (1797-1875) forced biogeographers to become much more cognizant of time and process.

According to one theory popular at the time, a globally uniform climate allowed single primitive populations to live evenly distributed over the surface of the Earth. As climates became diverse, these single populations became increasingly fragmented. This view was soon supplanted by a belief in a separate centre of creation for each biological province. Lyell thought that species appeared piecemeal by some unknown but natural means, while Louis Agassiz (1807-1873) argued that they appeared all at once by divine fiat. The chief anomaly to be explained by these theories was the appearance of the same species in more than one province. Were these species created several times, once in each province, or might not species wander from province to province? Why was it that geographically neighbouring species tended to be so similar to each other? Together, geology and biogeography set the stage for Darwin's solution to the mystery of mysteries.

Because so much attention has been paid to the confrontation between biblical literalism and Darwin's theory, an equally important conflict has been all but ignored
- that between transcendental idealism and more empirical views of the world. At the time explanations in terms of "archetypes" and "ideal plans" were considered perfectly legitimate on the Continent. Showing that several species all exhibited the same Bauplan explained the similarities exhibited. This view of science was just beginning to get a good toe-hold in the British Isles through the work of Richard Owen (1804-1892), Edward Forbes (1815-1854) and that rising young talent, T.H. Huxley (1825-1895). Forbes, for example, explained the geological distribution of fossil species in terms of the action of the principle of polarity acting from opposite ends of an ideal sphere. Other nineteenth-century scientists in Great Britain, such as Lyell and Darwin, could make no sense of such "explanations". They failed to see how they explained anything. Explaining the similarities exhibited by species in terms of common ancestors, that was quite a different matter. As Browne argues, the Darwinian revolution was as much a triumph of a particular view of science as it was of a particular view of the origin of species.

As the reader can surely tell from this review, Browne has accomplished the impossible. She has written a scholarly yet entertaining history of one of the most fascinating series of episodes in science. As anyone who reads the pages of this journal also knows, the story is far from over as dispersalist biogeographers do battle with vicariance and panbiogeographers; even a latter-day version of transcendental idealism has cropped up again. The possibility of checkmate in this game continues to recede into the distant future as ineluctably as the waters of the Great Flood receded from Mount Ararat.

David L. Hull is Distinguished Professor in the Department of Philosophy at the University of Wisconsin-Milwaukee, Wisconsin.

\section{IMAGE \\ UNAVAILABLE FOR COPYRIGHT REASONS}

